\title{
The Influence of Tourists Motivation on Tourists Satisfaction and its Impact Towards The Destination Loyalty: Muslim Travelers in Aceh
}

\author{
M. Ridha Siregar ${ }^{1}$, R. B. Radin Firdaus ${ }^{2}$, Zahri Bin Hamat ${ }^{3}$, Muhammad Ilhamsyah \\ Siregar $^{4}$, Abdul Muzammil ${ }^{5}$ \\ \{m.ridhasiregar@unsyiah.ac.id ${ }^{1}$, radin@usm.my², zahri@usm.my ${ }^{3}$, ilham@unsyiah.ac.id ${ }^{4}$, \\ amiemuzammil@gmail.com ${ }^{5}$ \}
}

Faculty of Economic and Business, Syiah Kuala University, Indonesia ${ }^{12345}$

\begin{abstract}
This study aims to determine the effects of Tourist Motivation on Tourists satisfaction and its Impact towards the Destination Loyalty. The samples used in this study were foreign and domestic tourists who visited Banda Aceh as many as 160 respondents. The equipment of data collection used in this study was a questionnaire. The sampling technique used was purposive sampling. The analytical method used was Partial Least Square (PLS) in order to determine the effects of the variables involved. The results showed that Tourism Motivation (PUSH and PULL) significantly affects Tourists Satisfaction and Tourists Satisfaction significantly affects the destination loyalty.
\end{abstract}

Keywords: Tourism Motivation, Push and Pull, Tourists Satisfaction, Loyalty Destination

\section{Introduction}

Aceh is a province located in the western tip of Indonesia. This strategic location serves Aceh as an entry point in the Malacca Strait and is at the same time becomes an Islamic tourist destination region. Aceh which applies Islamic sharia has made it becoming one of the provinces which have Islamic values in Indonesia. Aceh is a region that has strong historical, cultural, and spiritual values. Aceh is also dubbed the veranda of Mecca or Serambi Mekkah which has many potential halal tourism concepts in the form of; religious tourism, natural tourism, artificial tourism and cultural tourism with beautiful architecture and breath-taking scenery. "Aceh already has a spirit as a halal tourist destination because of all the aspects of life are based on the Islamic law, which therefore makes its branding, is strong". Said the speaker from the Indonesian Ministry of Tourism (Kemenpar) in a Halal Tourism Destination Development workshop by the Indonesian Ministry of Tourism at Oasis Hotels, Banda Aceh, Thursday $(03 / 24 / 2016)$.

In line with the growing of halal tourism in the world, Aceh government has tried to strengthen the current position of Aceh as Indonesia's halal tourist destination. As the matter of fact, The Indonesian Minister of Tourism, Arief Yahya (2016) (1) nominated three provinces in Indonesia to accelerate the world's halal tourist destinations. Alhamdulillah, Aceh is one of them, besides West Sumatra and West Nusa Tenggara which refers to the World Halal Travel Awards (WHTA) on October 19-21 2015 in the United Arab Emirates (UAE). 
However, it is unfortunate that some aspects of the tourism potential above are still having lack of attention from any related parties involved especially in terms of supporting the community, for example, such as cleanliness and maintenance of the neglected historical sites. Meanwhile, halal tourism is a new concept that reflects tourism based on Islamic teachings and ethical laws which represents activities under Islamic teachings, such as behaviour, clothing and products. On the other hand, a person's decisions to travel are influenced by the strong driving factors and pull factors. These driving and pulling factors are actually internal and external factors that motivate tourists to make decisions on travelling.

The driving factor is generally relating with the socio-psychological or which is acknowledged as a person specific motivation, therefore by having the driving factors, then it drives someone to travel eventhough he or she doesn't know where to travel yet. While pulling factors are destination-specific attributes. This factor is related to the presence of tourist attractions at the region or at the tourist destination sites. These tourist attractions can be in the form of fame objects, places that are widely discussed, and becoming the news trending topics. The urge to visit friends or family or the desire to watch art and ongoing sporting events is also an attraction at tourist destination sites.

For instance, Banda Aceh has been known among the international and domestic tourists as one of hallal tourism destination sites in Aceh. The driving factors that has made Muslim tourists visit Banda Aceh is an Islamic culture that has already attached to the name Aceh as the city of Serambi Mekkah. This Islamic culture in Aceh also becomes a special attraction to be studied in relation with the name attached whether the things which are related to dance, dress, music, art, folklore, and so on. As the result it can be a media to be used to educate people who come from outside of Aceh and also from the Aceh region itself which is famous for its culture of tolerance even though it lives with several different religions.

Besides that, currently the new look of Baiturrahman Grand Mosque is becoming an icon that has added value as the halal tourism. The design of the mosque that resembles a mosque in Medina is becoming a public conversation that encourages every body to see it directly. Apart from this, the history of mosques in Aceh is something interesting to be learned.

Many things that outsiders want to know and to learn about the history of Aceh. One of them is the Tsunami Museum, which is motivate the tourists to visit Banda Aceh for the reason that they want to find out about the devastating past disaster in 2004, and this is the only Tsunami Museum in Indonesia and other Tsunami tourism sites. In addition, tourists do not want to miss the panorama of natural tourism. This makes tourism marketers compete in providing the halal tourism. It can be seen from the number of tourist arrivals both international tourists and the domestic tourist continue to increase since the last five years. 


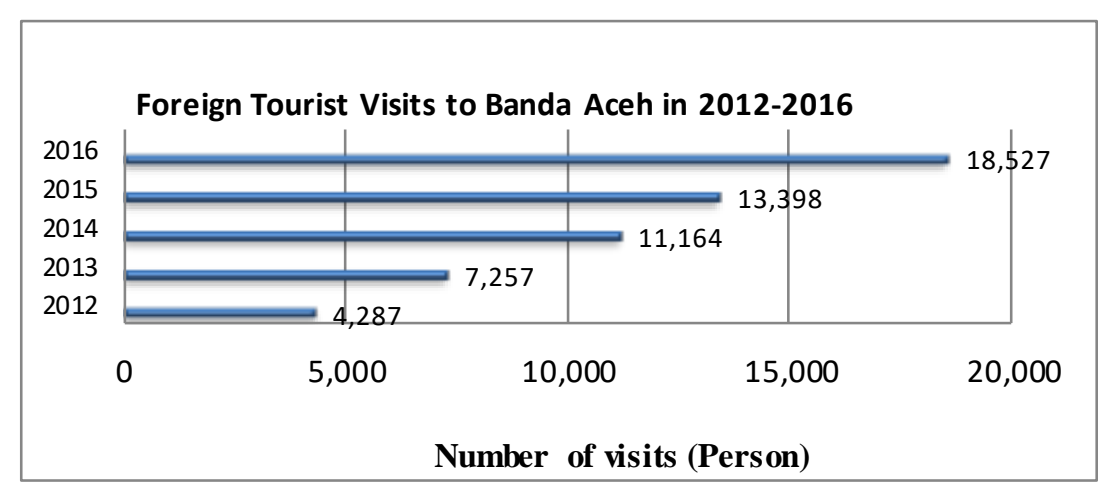

Fig.1. International Tourist Visits to Banda Aceh in 2012-2016 Source: Banda Aceh Statistic Center (processed by researchers, 2017)

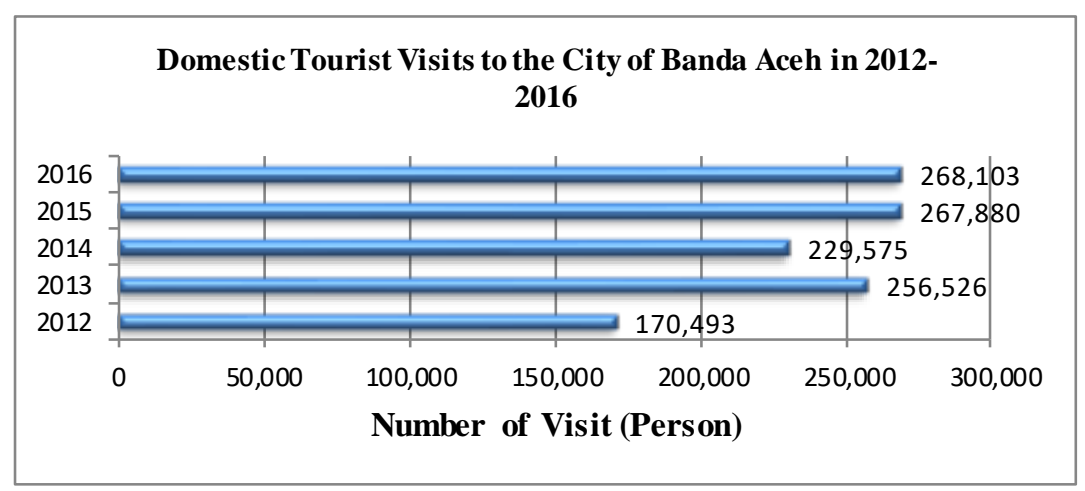

Fig.2. Domestic Tourist Visits to Banda Aceh in 2012-2016

Source: Banda Aceh Statistic Center (processed by researchers, 2017)

Among the intense competition and market saturation, tourism marketers need an understanding that can affect tourist satisfaction and destination loyalty from tourists. In particular, it is very important to understand how tourism motivational factors can influence tourist satisfaction and destination loyalty. The ultimate goal of tourism marketers should understand whether tourism motivation and tourist satisfaction are truly as the key elements that can cause tourists to continue to come to visit certain destinations. In addition, it is also important to determine whether the relationship can be applied to all segments or only for certain segments. In this case, the most important target market for tourist destinations is Muslim tourists. Based on the background that has been described, This study aims to determine the effects of Tourist Motivation on Tourists satisfaction and its Impact towards the Destination Loyalty. 


\section{Literature Reviews}

\subsection{Destination Loyalty}

According to Kotler and Keller (2012: 207). loyalty is a commitment that is firmly held to buy or back to a choice of a product or service in the future eventhough with the situational influences and the marketing efforts have the potential to cause consumers to switch to other products (2). Furthermore Griffin in Foster (2008: 170) describes of how to create the customers who are loyal by a company that is very depend on the company's ability to create value, and continuously strive to improve it (3),(4). Rewards from loyalty are long-term and cumulative. In an effort to get loyal customers, the company must develop a more accurate strategy, including improving service quality and product quality and knowing the position of competitors and estimating the size of the market share. Lovelock (2005: 133) states that customer loyalty is the customer's decision to voluntarily continue to subscribe to certain companies in the long term (5). Customer loyalty, can also be called a continuous positive buying behavior from customers towards certain companies or brands, clearly influenced by customer satisfaction.

Furthermore Ali Hasan (2008: 83) states that customer loyalty is defined as the person who buys, especially those who buy regularly and repeatedly (6). The customer is someone who continuously and repeatedly comes to the same place to satisfy his desires by having a product or service and paying for the product or service. Then Gremler and Brown in Ali Hasan (2008: 83) argue that customer loyalty is a customer who is not only repurchases an item or service, but also has a positive commitment and attitude towards service companies, for example by recommending other people to buy. Griffin in Diah Dharmayanti (2006: 38) argues that loyal customers are customers who are very satisfied with certain products or services so they have the enthusiasm to introduce them to anyone known (7),(8)(9).

Engel, Blackwell, Miniard in Ali Hasan (2008: 84) suggest that customer loyalty is a habit of repetition behavior, linkages and high involvement in the choice, and characterized by external information search and alternative evaluation (6). Meanwhile Alida Palilati (2004: 67) says that loyalty to a company's product or service (brand) is defined as a favorable attitude towards a brand, which is presented in purchases that are consistent with the brand at all times(10). A loyal customer has specific prejudices about what to buy and from whom. The purchase is not a random event. In addition, loyalty shows the condition of the duration of time and requires that no less than two times (4).

\subsection{Toirism Motivation}

Basically someone traveling is motivated by several things. From the various motivations that drive travel, McIntosh (1977) and Murphy (1985) say that motivation can be grouped into four major groups, namely as follows (11),(12):

a. Physical or physiological motivation (physical or physiological motivation), among others, for relaxation, health, comfort, participating in sports, relaxing and so on.

b. Cultural motivation, namely the desire to know the culture, customs, traditions and arts of other regions. It also includes interest in various cultural heritage objects (historical buildings).

c. Social motivation or interpersonal motivation (motivation that is social in nature), such as visiting friends and family, meeting work partners, doing things that are considered to bring prestige (prestige value), making pilgrimages, escaping from boring situations and so on. 
d. Fantasy motivation (motivation because of fantasy), namely the existence of fantasy that in other areas a person will be separated from the tedious daily routine, and ego-enhancement that gives psychological satisfaction. Also called status and prestige motivation.

According to motivation is an important factor for prospective tourists in making decisions regarding tourist destinations to be visited. Basically someone travels because they are motivated by several things (13).

According to motivation is also a phenomenon that is placed when individuals try to find satisfaction with their needs (14). In addition, they also connect between maslow's hierarchy of needs and travel motivation. From this context, the need for travel in order to escape from routine and saturation is a very basic psychological need that must be satisfied. also state that motivation occurs when the individual's needs are to be satisfied (14). In tourism research, the concept of motivation can be classified into two, which indicates that someone is traveling because there are driving and pulling factors that "force" them to do so (15).

Based on research by Uysal \& Hagan (1993)(16). Both of these factors explain how individuals are driven by motivational variables to the stage of making travel decisions and how they are drawn or interested in all the attributes given by tourist destinations. On the other hand, motivators of travel motivation are related to the desires of tourists, while motivational pullers are adjusted to the attributes of choice of tourist destinations (17),(18),(19),(20),(16),(21). Motivation to drive travel has more to do with internal and emotional aspects. Motivation attracts travel on the other hand, is related to external, situational and / or cognitive aspects. In a journey, tourists will be faced with a tourist destination option which he will go to this we usually call Travel Motivation (18). There are two important factors that motivate tourists to travel and make decisions about which tourist destinations to visit, namely:

a. Push Factors; The factor that drives a person to travel is to be released (even if only for a moment) from routine daily life, polluted environment, the speed of traffic and bustle in the city.

b. Pull Factors; These factors are related to the presence of tourist attractions in the area or at tourist destinations. These tourist attractions can be in the form of fame of objects, places that are widely discussed, and that are in the news tranding topic.

The urge to visit friends or family or the desire to watch art and ongoing sport events is also becoming an attraction in tourist destinations site.

Push and Pull are factors and their interests in shaping tourist motivation which are emphasized in study (22). Push is intangible factors that drive a tourist away from home, while pull is a real characteristic factor that attracts tourists towards their destination, referring to what makes attractive destinations for potential visitors including historical and cultural sources, beaches, and accommodations, represents the desire to overcome the feelings of isolation inherent in everyday life and only to be able to get away from it all (23)(24)(15).

Motivation driving to travel can be seen as a desire to 'escape', relaxation, prestige, health, adventure and social interaction, family togetherness and mere pleasure (18). Motivation attractors come from tourist destinations themselves, such as beaches, recreational facilities, culture, entertainment, natural scenery, shopping centers and theme parks. These attributes can be simulated and are increasingly reinforcing and in line with the driving motivation of travel (25).

Some researches have been built using these perspectives (26),(21),(27). In its development, travel motivation (vocation motives) can be classified into two categories, namely driving and attracting factors (28). Included in the driving factors include cognitive processes and travel motivation, including socialization, novelty-seeking, adventure-seeking, dream fulfillment, and the need to 'break away' (the need for escape) (17). On the other hand, the towing factors consist 
of tangible and intangible cues from a specific goal that can 'direct' travelers aware of the needs of a travel experience, such as the nuances of interesting nature, food, and society (29).

\subsection{Tourists Satisfaction}

Tourist satisfaction can be seen from the concept of customer satisfaction. Kotler and Keller (2012: 128) mention in general, satisfaction is the feeling of someone happy or disappointed resulting from comparing the performance of a product that is felt (or results) with expectations (2). While according to James Barnes in Peppers and Rogers (2011:31), satisfaction is tied to what the customer gets from dealing with a company as compared to what he has to commit to those dealings or interactions (30). Satisfaction is the feeling that occurs when consumers make a positive evaluation or feel happy with their decision (31).

Ratnasari and Aksa (2011: 117) state that customer satisfaction can be influenced by product quality, service quality, emotional and price (32). In addition, experience is one factor as stated by Fornell, Bitner and Hudson in AiCam (2011: 9) as a comparison, cumulative customer satisfaction is an overall evaluation based on total purchases and consumption experience with goods or services over time. Then according to PJ (33). Johnson in Purwoko (2000) suggests that a customer's satisfaction can be seen from the level of customer acceptance obtained (34)(35).

\section{Research Model and Hypotesis}

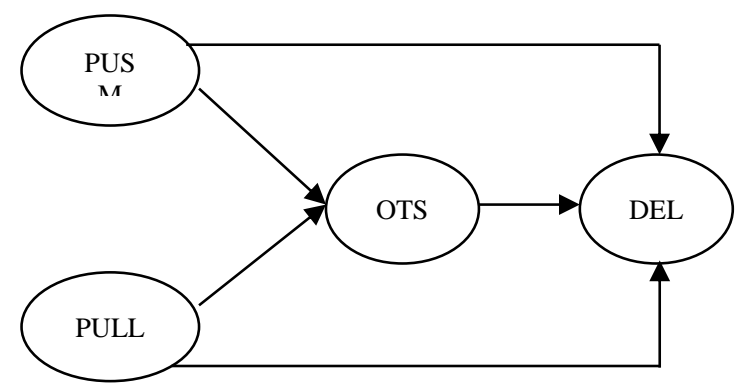

Fig.3. Research Model

Based on the research background, problem formulation, research model framework, the hypothesis in this study can be formulated as follows:

H1: Push motivation has an effect on tourists satisfaction

H2: Push motivation has an effect on tourists satisfaction

H3: Tourists satisfaction affects destination loyalty

H4: Push Motivation, Pull Motivation, and tourists satisfaction affect destination loyalty

\section{Method}

\subsection{Population and Sample}


This study is included in the type of descriptive-quantitative research using survey method by distributing questionnaires. Questionnaires will be distributed in the destinations area in Aceh, Due to the number of population in this study is unknown, then the sampling is done by multiplication method carried recommending a minimum number of samples is 5 times the number of questions in the questionnaire (36),(37),(25). The indicators in this study consist of 2 exogenous variables, 2 endogenous variables. With a number of consideration and match every statement in previous studies with the study that we would do, we specify that there were 5 indicators adapted (36). For destination loyalty,15 indicators for pull motivation and 8 indicators for push motivation that were adapted and 5 indicators for tourist satisfaction that adapted (38),(39). Thus, total questions in this study were 32 questions, so the minimum sample size in this study was $32 \times 5=160$. So the number of samples taken in this study was 160 respondents.

\subsection{Measurement Scale and Data Analysis}

To measure variables, this study uses an interval scale with a Likert scale based on five ranges. Likert Scale can be used to measure statement items that are positive or negative for the problem under study. Measurement of variables using interval scale, which is a measuring device that can produce measurements that allow calculation of averages, standard deviations, statistical tests of parameters, correlation and so on (40). Data analysis equipment used in this study is to find out how the influence of tourism motivation on tourists satisfaction and its impact on destination loyalty; Muslim tourists in Banda Aceh are SEM-based variants namely Partial Least Square (PLS) and using SmartPLS 3.0 software.

\section{Result and Discussion}

\subsection{Validity and Reliability Test}

The research variables used in the study are the results of a set of indicators obtained from the results of questionnaire distribution so that the resulting data needs to be tested for truth or validity. There are two components to test construct validity, namely the first convergent validity determined by the loading factor and AVE with the requirement of loading factor above 0.7 , and the AVE value of 0.5 (41). But because this research is developmental, the value of the loading factor above 0.5 is still acceptable, and the average variance extracted (AVE) value is above 0.50 (42).

The use of indicators as question items from research variable data requires a consistency test through reliability testing, so that the data used is truly reliable or meets the reliability aspects for further analysis. Reliability test in this study uses two measures of reliability of research instruments, namely reliability composite and cronbach's alpha. Composite reliability must be above 0.70 and cronbach's alpha is above 0.60 (42). This test is carried out only once for each variable. If the degree of data reliability is greater than the alpha coefficient $(\alpha)$, then the measurement results can be considered as a measurement tool with a level of accuracy and consistency of good thinking. 


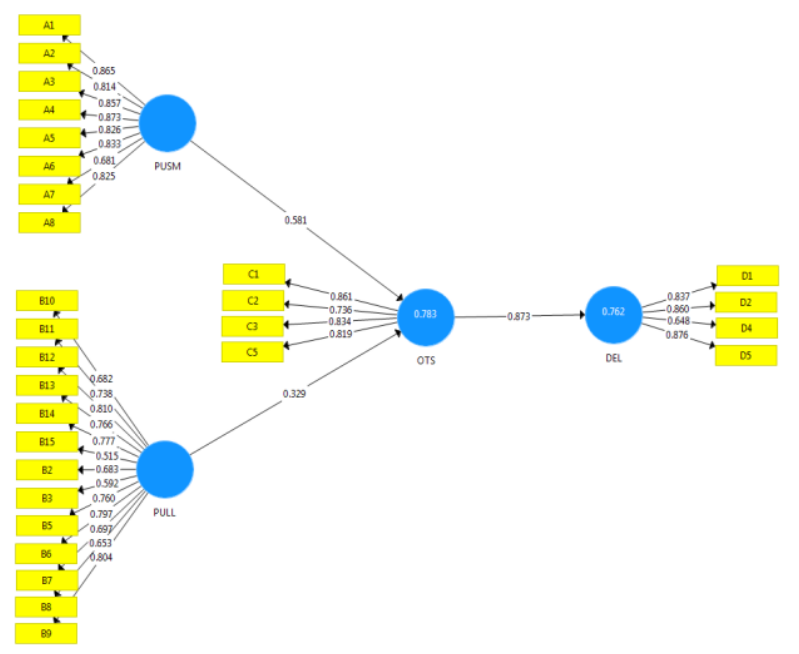

Fig.4. Display of Ouput Indicator Loading Source: Output SmartPLS 3.0 (2018)

Table 1. Display Output Indicator Loading convergent validity

\begin{tabular}{|c|c|c|c|}
\hline Indicator & DEL $\quad$ OTS & PULL & PUSM \\
\hline A1 & & & 0,865 \\
\hline A2 & & & 0,814 \\
\hline A3 & & & $\mathbf{0 , 8 5 7}$ \\
\hline A4 & & & 0,873 \\
\hline A5 & & & 0,826 \\
\hline A6 & & & $\mathbf{0 , 8 3 3}$ \\
\hline A7 & & & 0,681 \\
\hline $\mathbf{A 8}$ & & & 0,825 \\
\hline B10 & & 0,682 & \\
\hline B11 & & $\mathbf{0 , 7 3 8}$ & \\
\hline B12 & & $\mathbf{0 , 8 1 0}$ & \\
\hline B13 & & 0,766 & \\
\hline B14 & & 0,777 & \\
\hline B15 & & 0,515 & \\
\hline B2 & & 0,683 & \\
\hline B3 & & 0,592 & \\
\hline B5 & & $\mathbf{0 , 7 6 0}$ & \\
\hline B6 & & $\mathbf{0 , 7 9 7}$ & \\
\hline B7 & & 0,697 & \\
\hline
\end{tabular}




\begin{tabular}{lll}
\hline B8 & & $\mathbf{0 , 6 5 3}$ \\
\hline B9 & & $\mathbf{0 , 8 0 4}$ \\
\hline C1 & $\mathbf{0 , 8 6 1}$ & \\
\hline C2 & $\mathbf{0 , 7 3 6}$ & \\
\hline C3 & $\mathbf{0 , 8 3 4}$ & \\
\hline C5 & & $\mathbf{0 , 8 1 9}$ \\
\hline D1 & $\mathbf{0 , 8 3 7}$ & \\
\hline D2 & $\mathbf{0 , 8 6 0}$ & \\
\hline D4 & $\mathbf{0 , 6 4 8}$ & \\
\hline D5 & $\mathbf{0 , 8 7 6}$ & \\
\hline
\end{tabular}

Table 1. above explains that ouput indicator loadings of each indicator for each variable has met the convergent validity requirements for reflective constructs with loading factors above 0.6 except B1, B4, C4 and D3 where $0.364,0.378,0.221$ and 0.368 which do not meet the conditions for loading factors are removed.

Table 2. Display of AVE Results

\begin{tabular}{lc}
\hline Indicator & Average Variance Extracted (AVE) \\
\hline $\boldsymbol{D E L}$ & 0,657 \\
\hline $\boldsymbol{O T S}$ & 0,662 \\
\hline $\boldsymbol{P U L \boldsymbol { L }}$ & 0,516 \\
\hline $\boldsymbol{P U S M}$ & 0,679 \\
\hline
\end{tabular}

The value of AVE 0.5 indicates that the construct explains more than half of the variants of the indicators (41).

Table 3. Display of Cross Loading results in discriminant validity

\begin{tabular}{lllll}
\hline Indicator & DEL & OTS & PULL & PUSM \\
\hline $\mathbf{A 1}$ & 0,721 & 0,819 & 0,724 & $\mathbf{0 , 8 6 5}$ \\
\hline $\mathbf{A 2}$ & 0,812 & 0,679 & 0,669 & $\mathbf{0 , 8 1 4}$ \\
\hline $\mathbf{A 3}$ & 0,840 & 0,749 & 0,786 & $\mathbf{0 , 8 5 7}$ \\
\hline $\mathbf{A 4}$ & 0,796 & 0,766 & 0,807 & $\mathbf{0 , 8 7 3}$ \\
\hline $\mathbf{A 5}$ & 0,696 & 0,706 & 0,733 & $\mathbf{0 , 8 2 6}$ \\
\hline $\mathbf{A 6}$ & 0,739 & 0,715 & 0,778 & $\mathbf{0 , 8 3 3}$ \\
\hline $\mathbf{A 7}$ & 0,560 & 0,559 & 0,565 & $\mathbf{0 , 6 8 1}$ \\
\hline A8 & 0,708 & 0,713 & 0,728 & $\mathbf{0 , 8 2 5}$ \\
\hline B10 & 0,600 & 0,535 & $\mathbf{0 , 6 8 2}$ & 0,578 \\
\hline B11 & 0,600 & 0,600 & $\mathbf{0 , 7 3 8}$ & 0,609 \\
\hline
\end{tabular}




\begin{tabular}{lcccc}
\hline B12 & 0,683 & 0,695 & $\mathbf{0 , 8 1 0}$ & 0,696 \\
\hline B13 & 0,628 & 0,689 & $\mathbf{0 , 7 6 6}$ & 0,657 \\
\hline B14 & 0,693 & 0,678 & $\mathbf{0 , 7 7 7}$ & 0,705 \\
\hline B15 & 0,448 & 0,467 & $\mathbf{0 , 5 1 5}$ & 0,470 \\
\hline B2 & 0,647 & 0,636 & $\mathbf{0 , 6 8 3}$ & 0,680 \\
\hline B3 & 0,525 & 0,456 & $\mathbf{0 , 5 9 2}$ & 0,556 \\
\hline B5 & 0,656 & 0,645 & $\mathbf{0 , 7 6 0}$ & 0,704 \\
\hline B6 & 0,626 & 0,635 & $\mathbf{0 , 7 9 7}$ & 0,674 \\
\hline B7 & 0,498 & 0,564 & $\mathbf{0 , 6 9 7}$ & 0,553 \\
\hline B8 & 0,513 & 0,478 & $\mathbf{0 , 6 5 3}$ & 0,540 \\
\hline B9 & 0,692 & 0,685 & $\mathbf{0 , 8 0 4}$ & 0,740 \\
\hline C1 & 0,876 & $\mathbf{0 , 8 6 1}$ & 0,776 & 0,731 \\
\hline C2 & 0,523 & $\mathbf{0 , 7 3 6}$ & 0,528 & 0,541 \\
\hline C3 & 0,663 & $\mathbf{0 , 8 3 4}$ & 0,670 & 0,654 \\
\hline C5 & 0,721 & $\mathbf{0 , 8 1 9}$ & 0,724 & 0,865 \\
\hline D1 & $\mathbf{0 , 8 3 7}$ & 0,679 & 0,669 & 0,814 \\
\hline D2 & $\mathbf{0 , 8 6 0}$ & 0,749 & 0,786 & 0,857 \\
\hline D4 & $\mathbf{0 , 6 4 8}$ & 0,467 & 0,515 & 0,470 \\
\hline D5 & $\mathbf{0 , 8 7 6}$ & 0,861 & 0,776 & 0,731 \\
\hline Source: Output SmartPLS 3.0 & $(2018)$ & & \\
\hline
\end{tabular}

The criteria in cross loading is that each indicator that measures its construct must be correlated higher with its construct compared to other constructs (43). Based on the results of the cross loading table above, it can be seen that the loading factor for the PUSM indicator or the construct is larger than the other indicators such as PULL, OTS and DEL. For PULL variables or for constructs there is a greater loading factor compared to indicators such as PUSM, OTS and DEL. Similar to the OTS indicator which has a higher loading factor to the construct compared to the other three indicators. This also happens in DEL. So that the four variables in this study can be said to have good discriminant validity.

Table 4. Reliability Test Results

\begin{tabular}{lllll}
\hline No. & Variabel & $\begin{array}{l}\text { Cronbach's } \\
\text { Alpha }\end{array}$ & $\begin{array}{l}\text { Composite } \\
\text { Reliability }\end{array}$ & explanation \\
\hline 1. & DEL & 0,824 & 0,883 & Reliable \\
\hline 2. & OTS_ & 0,831 & 0,887 & Reliable \\
\hline 3. & PULL & 0,920 & 0,932 & Reliable \\
\hline 4. & PUSM & 0,932 & 0,944 & Reliable \\
\hline \multicolumn{2}{r}{ Source: Output SmartPLS $3.0(2018)$} & &
\end{tabular}


Based on Table 4.4 it can be seen that the composite reliability variable destination loyalty (DEL) has fulfilled the requirements above 0.70 which is equal to 0.883 . Likewise the value of cronbach's alpha is in accordance with the criteria above 0.60 which is equal to 0.824 , the tourists satisfaction variable (OTS) has fulfilled the requirements above 0.70 , namely composite reliability of 0.887 . Similarly, Cronbach's alpha value is in accordance with the criteria above 0.60 which is equal to 0.831 , the pull motivation (PULL) variable has a composite reliability value of 0.932 and the cronbach's alpha value is 0.920 , and the push motivation variable (PUSM) has a composite reliability value of 0.944 and the cronbach's alpha value is 0.932 . Thus all the questions used in this research variable can be said to be reliable because it fulfills the credibility of the reliability composite standard above 0.70 . and cronbanch's alpha with an alpha value of more than 0.60. Overall, the results of the measurement model (outer model) have met the requirements so that this study can proceed to the structural model (inner model).

Results of testing Hypothesis 1

Table 5. Path Coefficient in Testing the Direct Effect Model

\begin{tabular}{llllll}
\hline Indicator & $\begin{array}{l}\text { Original } \\
\text { Sample (O) }\end{array}$ & $\begin{array}{l}\text { Sample } \\
\text { Mean (M) }\end{array}$ & $\begin{array}{l}\text { Standard } \\
\text { Deviation } \\
\text { (STDEV) }\end{array}$ & $\begin{array}{l}\text { T Statistics } \\
(\mid \mathbf{O} / \text { STDEV|) }\end{array}$ & $\begin{array}{l}\text { P } \\
\text { Values }\end{array}$ \\
\hline PUSM -> OTS & 0,878 & 0,880 & 0,015 & 59,353 & 0,000 \\
\hline
\end{tabular}

Source: Output SmartPLS 3.0 (2018)

Results of testing hypothesis 2

Table 6. Path Coefficient in Testing the Direct Effect Model

\begin{tabular}{llllll}
\hline Indicator & $\begin{array}{l}\text { Original } \\
\text { Sample } \\
(\mathbf{O})\end{array}$ & $\begin{array}{l}\text { Sample } \\
\text { Mean }(\mathbf{M})\end{array}$ & $\begin{array}{l}\text { Standard } \\
\text { Deviation } \\
(\text { STDEV) }\end{array}$ & $\begin{array}{l}\text { T Statistics } \\
(\mid \mathbf{O} / \text { STDEV|) }\end{array}$ & $\begin{array}{l}\mathbf{P} \\
\text { Values }\end{array}$ \\
\hline PULL -> OTS & 0,840 & 0,844 & 0,019 & 44,121 & 0,000 \\
\hline Source: Output SmartPLS $3.0(2018)$ & & & &
\end{tabular}

As stated above, the hypothesis testing is based on the T-statistics value on the display of the bootstrapping output of the smartPLS 3.0 program with the t-table value. If T-statistics is higher than the t-table value, it means that the hypothesis is supported. The test uses a significance level of 5\%, has a t-table value of 1.97 for the number of respondents (n) of 160 . To reject / accept the hypothesis using probability then $\mathrm{Ha}$ is accepted if the p-value is smaller than 0.05 . In table 4.6 above the pull motivation variable towards tourists satisfaction has a coefficient of 0.840 , the T-statistic value is 44.121 and is greater than t-table which is 1.97 and the p-value is smaller than 0.05 .

The results of this test also support research (44). According to pull is a real characteristic factor that attracts tourists to their destination, referring to what makes attractive destinations for potential visitors including historical and cultural sources, beaches and accommodations (24).

Results of testing hypothesis 3 
Table 7. Path Coefficient in Testing the Direct Effect Model

\begin{tabular}{llllll}
\hline Indikator & $\begin{array}{l}\text { Original } \\
\text { Sample (O) }\end{array}$ & $\begin{array}{l}\text { Sample } \\
\text { Mean (M) }\end{array}$ & $\begin{array}{l}\text { Standard } \\
\text { Deviation } \\
\text { (STDEV) }\end{array}$ & $\begin{array}{l}\text { T Statistics } \\
(\mid \text { O/STDEV|) }\end{array}$ & $\begin{array}{l}\text { P Values } \\
\text { OTS -> DEL }\end{array}$ \\
\hline
\end{tabular}

Source: Output SmartPLS 3.0 (2018)

From the table 7 it can be acknowledged that the effect of tourists satisfaction variable on destination loyalty is 0.877 , the value of T-statistic is 66.813 and is greater than the t-table value which is 1.97 and the p-value is 0.000 , which means less than 0.05 . Thus hypothesis 3 can be proven, meaning that the more satisfied tourists are with push and pull motivation, the higher the destination loyalty of tourists to attractions in Banda Aceh.

The results of this test support which states that travel motivation (push and pull) significantly and positively influences tourists tourists action, then influences destination loyalty (44)(45). Based on the research both factors (push and pull) explain how individuals encourage the making of travel decisions and how they are drawn or interested in all the attributes given by tourist destinations (16).

Referring to argues that loyal customers are customers who are very satisfied with certain products or services so they have enthusiasm to introduce them to anyone (7). Supports that detention loyalty is influenced by overall satisfaction (46).

\section{Hypothesis Testing Results 4}

Destination Loyalty as an endogenous variable is predicted by three exogenous variables namely push motivation, pull motivation and tourists satisfaction. The following is the calculation of the effect of exogenous variables simultaneously on destination loyalty using the F Test:

$$
\begin{aligned}
& \text { F test }=\frac{0,762 / 3}{(1-0,762) /(160-3-1)} \\
& F \text { test }=\frac{0,254}{(0,238) /(156)}=\frac{0,254}{0,001525}=\mathbf{1 6 6 , 5 5 7}
\end{aligned}
$$

After simultaneous hypothesis testing, the results show that there are influences of push motivation, pull motivaton and tourists satisfaction variables together on destination loyalty showing that the Fcount value is 166,557 and the value is greater than Ftable $=3,052(\mathrm{df}=2$ / $\mathrm{n}=160$ ) Then $\mathrm{H} 0$ is rejected and Ha is accepted.

\subsection{Conclusion and Future Study}

Based on the results of research that has been discussed, it can be concluded that: 
a. The test results show that push motivation has a significant effect on tourists satisfaction.

b. The test results show that pull motivation has a significant effect on tourists satisfaction.

c. The test results show that tourists satisfaction affects destination loyalty.

d. The test results show that push motivation, pull motivation and tourists satisfaction simultaneously have a significant effect on destination loyalty.

For further purposes, there are a number of suggestions put forward by the author that can be considered by the next researcher and company, as follows:

a. The next researcher is expected to be able to trace more research relevant to this study in order to get comprehensive and complete comparisons so that further research can produce better and more accurate results.

b. The author suggests the next researcher to conduct more in-depth research on the Effect of Tourism Motivation on Tourists Satisfaction and Its Impact on Destination Loyalty. Because in the research of Tourism Motivation (PUSH and PULL) it affected $78.3 \%$ of Tourists Satisfaction while other variables that affected Tourists Satisfaction were $21.7 \%$. And tourists satisfaction affects destination loyalty by $76.2 \%$.

c. It is expected that tourism managers and service providers both hotel and travel in Banda Aceh can manage, maintain and make improvements to tourist objects, and provide good service so that it can lead to satisfaction (Tourists Satisfaction) which can ultimately create loyalty (Destination Loyalty).

\section{References}

1. Yahya A. CEO Message \#18 Pariwisata sebagai Core Economy Negara. Retrieved 4th of February, 2017, from the Ministry of Tourism of the Republic of Indonesia. 2017; Available from: kemenpar.go.id/asp/detil.asp?c=193\&id=3443

2. Kotler P and KLK. Manajemen Pemasaran. Terjemahan Bob Sabran. 13th ed. Jakarta: Erlangga; 2012.

3. Bob F. Manajemen Ritel. Bandung: Alfabeta. Eng Technol. 2008;5(6):15.

4. Griffin J. Griffin, Jill. 2003. Customer Loyalty. Jakarta: Erlangga. Jakarta: Erlangga; 2003.

5. Lovelock C. Manajemen Pemasaran Jasa. Jakarta: PT. Indeks Kelompok Gramedia; 2005.

6. Hasan A. Manajemen Pemasaran dan Marketing. Bandung: CV. Alfabeta.: CV. Alfabeta; 2008.

7. Dharmayanti D. ANALISIS DAMPAK SERVICE PERFORMANCE DAN KEPUASAN SEBAGAI MODERATING VARIABLE TERHADAP LOYALITAS NASABAH ( Studi pada Nasabah Tabungan Bank Mandiri Cabang Surabaya ). J Manaj Pemasar. 2006;1:35-43.

8. Griffin J. Customer Loyalty,Menumbuhkan Dan Mempertahankan Kesetian Pelanggan. Alih bahasa Dwi Kartini Yahya. Jakarta: Erlangga.: Erlangga; 2010.

9. Musanto T. FAKTOR-FAKTOR KEPUASAN PELANGGAN DAN LOYALITAS PELANGGAN: Studi Kasus Pada CV. Sarana Media Advertising Surabaya. J Manaj dan Wirausaha. 2004;6(2):123-36.

10. Palilati A. Pengaruh Tingkat Kepuasan Terhadap Loyalitas Nasabah Tabungan Perbankan di Wilayah Bugis. J Ilmu-Ilmu Sos. 2014;65-74.

11. McIntosh. Karakteristik Wisatawan. Yogyakarta: Andi. 1997;

12. Murphy PE. Tourism A Community Approach. Meutheun: New York. 1985;

13. Pitana, I. Gede dan Gayatri PG. Sosiologi Pariwisata. Yogyakarta: Andi. 2005;

14. Mill R van M. The Tourism System. New Jersey: Prentice Hall International. 1985;

15. Dann GMS. Anomie, ego-enhancement and tourism. Ann Tour Res. 1977;4(4):184-94.

16. Uysal, M., dan Hagan LAR. Motivation Of Pleasure Travel And Tourism. In A VNR'S

Encyclopedia of Hospitality and Tourism. New York-NY: van Nostrand Reinbold; 1993. 798- 
$810 \mathrm{p}$.

17. Chon KS. Understanding Recreational Traveller's Motivation, Attitude, And Statisfaction. The Tourist Review. 1989;44. No. 01:3-7.

18. Crompton J. Motivation of Pleasure Vocations. Ann Tour Res. 1979;6(4):408-24.

19. Dann G. Tourist Motivation-An Apprasial. Ann Tour Res. 1981;8(2):187-219.

20. Chul Oh H, Uysal M, Weaver PA. Product bundles and market segments based on travel motivations: a canonical correlation approach. Int J Hosp Manag. 1995;14(2):123-37.

21. Uysal M, Li X, Sirakaya-turk E. Push-Pull Dynamics in Travel Desicions. In H. Oh \& A. Pizam (Eds.), Handbook of Hospitality Marketing Management. Oxford, Unied Kingdom:

Butterworth-Heinemann.Push - pull dynamics in travel decisions. 2008;412-39.

22. Crompton JL, McKay SL. Motives of visitors attending festival events. Ann Tour Res. 1997;24(2):425-39.

23. Baker DA, Crompton JL. Quality, satisfaction and behavioral intentions. Ann Tour Res. 2000;27(3):785-804.

24. Bigné JE, Andreu L, Gnoth J. The theme park experience: An analysis of pleasure, arousal and satisfaction. Tour Manag. 2005;26(6):833-44.

25. Schumacker, R. E., \& Lomax RG. A Beginner's Guide To Structural Equation Modeling. Mahwah, NJ: Lawrence Erlbaum. 1996.

26. Iso-Aloha ES. Toward a Social Psychological Theory of Tourism Motivation: A Rejoinder. Ann Tour Res. 1982;6.

27. Yuan, S., \& McDonald C. Motivational Determinants of International Pleasure Time. J Travel Res. 1990;24(01):42-4.

28. Graham D. Tourism motivation: an apprasial. Ann Tour Res. 1989;8(2):187-219.

29. Sirakaya E, Sheppard AG, McLellan RW. Assessment of the relationship between perceived safety at a vacation site and destination choice decisions: Extending the behavioral decisionmaking model. J Hosp Tour Res. 1997;21(2):1-10.

30. Peppers, Don dan Rogers M. Managing Customer Relationship, second edition. New Jersey: Hoboken; 2011.

31. Hoyer, W. D. \& MacInnis DJ. Consumer Behavior. South-Western: pre-Press, PMG. 2010;5.

32. Ratnasari RT\& MHA. Ratnasari, Ririn Tri \& Mastuti H. Aksa. 2011. Manajemen Pemasaran Jasa. Bandung: Ghalia Indonesia. Bandung: Ghalia Indonesia; 2011.

33. Cham TTA. Explaining Tourists Satisfaction and Intention To Revisit Nha Trang, Viet Nam. 2011;(May):1-78.

34. Edvardsson B, Johnson MD, Gustafsson A, Strandvik T. The effects of satisfaction and loyalty on profits and growth: Products versus services. Total Qual Manag. 2000;11(7).

35. Nasution MN. Manajemen Mutu Terpadu (Total Quality Management). Jakarta: Ghalia Indonesia; 2001.

36. Bentler, P. M., \& Chou C-P. Practical issues in structural modeling. Sociological Methods \& Research. 1987;16:78-117.

37. Hair, J. F. et al. Multivariate Data Analysis. Vol. 6. New Jersey USA: Pearson Education, Inc; 2010 .

38. Esichaikul R. Travel Motivation, Behavior and Requirements of European Senior Tourists To Thailand. Sukhothai. Journal of Thammathirat Open Universsity (Thailand). PASOS Rev Tur y Patrim Cult. 2012;10(2).

39. Kotler PKKL. Marketing Management. 13th ed. New Jersey: Pearson Prentice hall.; 2009.

40. Ferdinand AT. Metode Penelitian Manajemen: Pedoman Penelitianuntuk skripsi, Tesis dan Disertai Ilmu Manajemen. Semarang: Universitas Diponegoro. Universitas Diponegoro; 2006.

41. Hair Jr. J. F, Hult G. T., Ringle C. M. \& SM. A Primer on Partial Least Squares Structural Equation Modeling (PLS-SEM). California: SAGE Publication; 2014.

42. Abdillah W\& J. Partial Least Square (PLS) Alternatif Structural Equation Modeling (SEM) dalam Penelitian Bisnis. Edisi 1. Yogyakarta: ANDI. 2015.

43. Yamin S dan HK. Generasi Baru Mengolah Data Penelitian dengan Partial Least Square Path Modelin: Aplikasi dengan software XLSTAT, SmartPLs dan Visual PLS. Jakarta : Salemba 
Infotek. 2011;

44. Battour MM, Battor MM, Ismail M. The mediating role of tourist satisfaction: A study of Muslim tourists in Malaysia. J Travel Tour Mark. 2012;29(3):279-97.

45. Yoon Y, Uysal M. An examination of the effects of motivation and satisfaction on destination loyalty: A structural model. Tour Manag. 2005;26(1):45-56.

46. Bitner, Mari Jo, Zeithaml VA. Service Marketing.Boston: MCCGraw-Hill. 1996. 1. 